Journal of Agricultural Sciences
(Tarim Bilimleri Dergisi)

\title{
Exogenously Applied GA3 Promotes Plant Growth in Onion by Reducing Oxidative Stress Under Saline Conditions
}

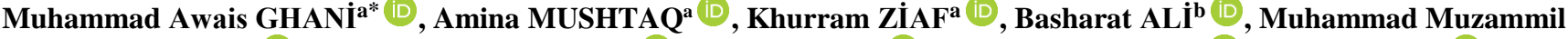

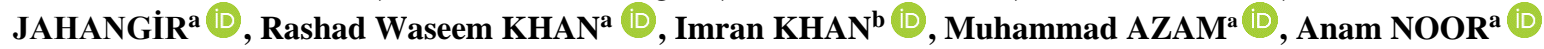 \\ ${ }^{a}$ Institute of Horticultural Sciences, University of Agriculture, Faisalabad 38040, PAKISTAN \\ ${ }^{b}$ Department of Agronomy, University of Agriculture, Faisalabad 38040, PAKISTAN
}

\section{ARTICLE INFO}

Research Article

Corresponding Author: Muhammad Awais GHANI, E-mail: awais.ghani@uaf.edu.pk

Received: 18 September 2019 / Revised: 15 December 2019 / Accepted: 16 December 2019 / Online: 31 May 2021

\section{ABSTRACT}

Onion (Allium cepa L.) is a biennial crop of high commercial value in Pakistan. Onion is considered as salt sensitive plant species. The present investigation was carried out to investigate the effect of salinity on onion and its alleviation through exogenously applied gibberellic acid $\left(\mathrm{GA}_{3}\right.$; $\left.100 \mathrm{mg} \mathrm{L}^{-1}\right)$. Foliar application of $\mathrm{GA}_{3}\left(100 \mathrm{mg} \mathrm{L}^{-1}\right)$ was applied on onion seedlings grown under three levels $\left(0,2\right.$ or $\left.4 \mathrm{dS} \mathrm{m}^{-1}\right)$ of salinity after 45 days of sowing. Results revealed that growth parameters and total soluble protein (TSP) contents declined with increase in soil salinity level. While, antioxidant enzyme activities (CAT, SOD and POD) were increased with salinity. However, exogenously applied GA3 significantly enhanced the plant growth and TSP in onion seedlings. Interestingly, CAT, SOD and POD concentration decreased with $\mathrm{GA}_{3}$ application which depicts stress alleviation in saline stressed onion plants due to $\mathrm{GA}_{3}$. It was concluded that the growth of onion could be enhanced to some extent by the application of $\mathrm{GA}_{3}$ under salinity stress.

Keywords: Allium cepa, PGRs, Saline stress, Antioxidative response, Yield

(C) Ankara University, Faculty of Agriculture

\section{Introduction}

Onion (Allium cepa L.) is a biennial crop, and it belongs to Alliacea family (Adamicki \& Kepka 1974). It is the one of most popular vegetables in the daily diet. Onion is an important commercial crop for the economy of Pakistan (FAO 2012). Salinity has adverse effect on growth and production of agricultural crops (Munns \& Tester 2008). Studies showed that due to the saline toxicity every aspect of physiological and biochemical of plant is effect. (Khan \& Panda 2008). Plants face two basic problems under saline conditions. Firstly, excessive salt lower down the osmotic potential in soil solution which reduces uptake of water in plant. Secondly, maximum $\mathrm{Na}^{+}$and $\mathrm{Cl}^{-}$ions uptake diverts the absorption rate of essential minerals and ascribe toxicity to plants (Tester \& Davenport 2003). Specific ion toxicities damaged the tissues of transpiring leaves which occur due to boron, sodium, and chloride accumulation. This accumulation of adverse ions may reduce protein synthesis, photosynthesis, and inactivate enzymes, and also damaged chloroplasts as well as other plant organelles (Taiz \& Zeiger 2002).

Onion lacks tap root system and root hairs. Most of the root system is confined within top 20-25 cm of soil. Plant growth rate is half of other vegetables such as cauliflower and cabbage (Brewster 1994). Onion is more vulnerable to salinity than other vegetables, particularly the seedling emergence stage (Brewster 1994). Threshold electrical conductivity (EC) level for onions is $1.2 \mathrm{dS} \mathrm{m}^{-1}$ at $25^{\circ} \mathrm{C}$ and each unit change in EC cause about $16 \%$ reduction in yield (Allen et al. 1998).

Gibberellic acid $\left(\mathrm{GA}_{3}\right)$ affects production by increasing the stem length and internodes of onion plant. It restricts senescence by change in lipid peroxidation and adjusts high level of cellular antioxidants like superoxide dismutase and catalase (Dhind sa et al. 1982). It also promotes the growth of the plant, promote cell division and cell extension (Olszewski et al. 2002; Ubeda et al. 2009). Sarkar et al. (2018) reported that $\mathrm{GA}_{3}$ at $60 \mathrm{mg} \mathrm{L}^{-1}$ increased bulb weight over the control under normal conditions. GA enhances the water use efficiency of tomato plants at low salinity level by reducing stomatal resistance (Maggio et al. 2010). So, in the present study, it was hypothesized that $\mathrm{GA}_{3}$ can alleviate salt stress in onion. Therefore, the present work was taken up under field conditions to determine the impact of different level of salinity on growth of onion and alleviation of stress by $\mathrm{GA}_{3}$. 


\section{Material and Methods}

The Phulkara genotype which is local variety was selected for this experimental study. Seeds were obtained from Punjab Food Corporation Faisalabad, Pakistan. The experiment was carried out in the vegetable experimental area of Institute of Horticultural Sciences (IHS), University of Agriculture Faisalabad, Pakistan in the year 2018 and 2019.

Seed sowing was done in soil pots containing $10 \mathrm{~kg}$ soil. Before the sowing of onion seeds, the electrical conductivity (EC) of the soil from representative area was calculated and compared to the results of real EC dS m${ }^{-1}$ of soil. Then artificially salinity was caused by adding the measured quantity of salt $(\mathrm{NaCl})$ in soil and mixed well according to get the desired salinity $\mathrm{dS} \mathrm{m}^{-1}$. The calculations were calculated according to the Rayment \& Higginson (1992) method. Measured quantity of salt was added to the soil and mixed well by the soil mixer to get the homogeneous mixture.

Then the experimental area was cleaned and layered with polythene tunnel sheet to avoid the leaching of salt in other soil. Inorganic fertilizers were supplied properly at the rate of $50 \mathrm{~kg} \mathrm{ha}^{-1} \mathrm{~K}$ as potassium sulphate, $50 \mathrm{~kg} \mathrm{ha}{ }^{-1}$ of $\mathrm{N}$ as urea and $80 \mathrm{~kg}$ $\mathrm{ha}^{-1}$ of $\mathrm{P}$ as di-ammonium phosphate. The six treatments were maintained as; $\left(\mathrm{T}_{0}\right)$ control; $\left(\mathrm{T}_{1}\right) \mathrm{GA}_{3}: \mathrm{GA}_{3} 100 \mathrm{mg} \mathrm{L}^{-1} ;\left(\mathrm{T}_{2}\right)$ salinity level: $2 \mathrm{dS} \mathrm{m}{ }^{-1} ;\left(\mathrm{T}_{3}\right)$ salinity level: $2 \mathrm{dS} \mathrm{m}{ }^{-1}+$ Gibberellic acid: $\mathrm{GA}_{3} 100 \mathrm{mg} \mathrm{L}^{-1} ;\left(\mathrm{T}_{4}\right)$ salinity level: $4 \mathrm{dS} \mathrm{m}^{-1} ;\left(\mathrm{T}_{5}\right)$ salinity level: 4 $\mathrm{dS} \mathrm{m}{ }^{-1}+$ Gibberellic acid: $\mathrm{GA}_{3} 100 \mathrm{mg} \mathrm{L}^{-1}$. The foliar spray of $\mathrm{GA}_{3}\left(100 \mathrm{mg} \mathrm{L}^{-1}\right)$ was applied after 45 days of sowing days. Onion plants were harvested after 135 days of $\mathrm{GA}_{3}$ application and different growth parameters were analyzed. Samples were saved in $-20{ }^{\circ} \mathrm{C}$ for biochemical analysis.

\subsection{Growth parameters}

The plant height was calculated by the scale from the tip of that plant to the base on ground. The length of the leaf blade was measured from the base of leaf of observing plant to the tip. It was done by using a scale meter. Evacuated plants were washed with clean water, straightened and after that its root length was estimating by utilizing a tape meter in centimeters and the average was taken for each replicate. The diameter of onion bulb was calculated at right angles to longitudinal axis at the widest form of the bulb of arbitrarily chosen plants in each plot by using veneer caliper (model 141) (Demisie \& Tolessa 2017).

Plants chosen from each treatment were harvested at the end of the experiment. Roots were removed from that plants then they were washed with water to expel the dirt and soil. Then root weight was measured by using weighing balance. Root dry weight was estimated by putting the sample in oven at $65^{\circ} \mathrm{C}$ for $72 \mathrm{hr}$ to dry the samples. At that point, weight was ascertained by adjust and the normal mean for each sample was figured.

\subsection{Germination percentage}

Data was recorded for germination on daily basis after one week of sowing seeds till 14 days. Germination percentage was then calculated by using the following formula:

Germination percentage $=\frac{\text { no.of germinated seeds }}{\text { Total no of seeds sown }} \times 100$

\subsection{Biochemical analysis}

Fresh samples were collected from the experimental area and stored at $-20{ }^{\circ} \mathrm{C}$. All the samples were crushed in $50 \mathrm{~mL}$ of 100 $\mathrm{mM}$ sodium phosphate $(\mathrm{pH} 7)$ buffer containing $0.5 \%(\mathrm{w} / \mathrm{v})$ polyvinyl pyrrolidone and $1 \mathrm{mM}$ ascorbic acid and homogenize mixture was prepared. After preparation of mixture sample were placed at $4{ }^{\circ} \mathrm{C}$ for 5 min. The collected mixture was filter by using filter paper and centrifuged it for $15 \mathrm{~min}$ at $5000 \mathrm{RPM}$ and the supernatant was collected.

Peroxidase (POD) was determined by using the method of (Onsa et al. 2004). In this method 4-methylecatechol was used as a substrate. To check the activity of POD reaction mixture was prepared by using 4-methylcatechol, $10 \mathrm{mM}$ sodium phosphate buffer, $5 \mathrm{mM} \mathrm{H} \mathrm{H}_{2} \mathrm{O}_{2}$ and $500 \mu \mathrm{L}$ of total volume of $3 \mathrm{~mL}$ crude extract of the sample at room temperature. By using spectrophotometer absorption was measured at $420 \mathrm{~nm}$.

Superoxide dismutase (SOD) activity was determined by using the method of (Kumar et al. 2012). Reaction mixture was prepared by using $0.2 \mathrm{mM}$ EDTA, $12 \mathrm{mM}$ L-methionine, $50 \mathrm{mM}$ buffer of sodium phosphate (pH 7 ) .10 uM riboflavin, $50 \mu \mathrm{M}$ NBT and $100 \mu \mathrm{L}$ of final volume of $3 \mathrm{~mL}$ of the crude extracted sample. The reaction mixture was incubated into the white light for $15 \mathrm{~min}$ at room temperature. After incubation of $15 \mathrm{~min}$ absorption was observed at $560 \mathrm{~nm}$ by using spectrophotometer.

Catalase (CAT) activity was measured by using the method of Aebi 1983. To calculate the CAT activity spectrophotometer was used. The reaction mixture was prepared by using $30 \mathrm{mM} \mathrm{H}_{2} \mathrm{O}_{2} 100 \mathrm{mM}$ sodium phosphate buffer (pH 7) and 100 $\mathrm{uL}$ crude extract of sample by volume of $3 \mathrm{~mL}$. Absorption was calculated at $240 \mathrm{~nm}$ at room temperature in spectrophotometer. 
The soluble protein (TSP) was measured according to Coomassie Brilliant Blue G-250 Staining Method (Sedmak \& Grossberg 1977).

\subsection{Statistical analysis}

All experiments were conducted in triplicate with two factorial randomized complete block design (RCBD) and all results were expressed as the average \pm standard error of the measurements. Statistix 8.1 software was used for statistics.

\section{Results and Discussion}

Data about growth parameters (plant height, root fresh and dry weight, leaf blade length, root length, bulb diameter and germination percentage) of treated and untreated plants of onion seedlings are shown in Table 1 . The foliar spray of $\mathrm{GA}_{3} 100 \mathrm{mg}$ $\mathrm{L}^{-1}$ showed significant effect on plant height, root fresh and dry weight, leaf blade length, root length, bulb diameter and germination percentage under salinity (Table 1). Previously, Ali et al. (2015) also found that application of GA 3 has positive impact on growth and yield of onion. However, salinity stress reduced the growth parameters as compared to the control conditions (El-Shaieny 2015; Nasri et al. 2017). As the salinity increased, there was a gradual decline in all growth parameters of onion (Stia-Baba et al. 2010). Similarly, results showed that when salinity level increased the plant growth declined as compared to control (Table 1). The decrease in plant growth in saline stress might be as a result of that salinity removes the potassium ions via plant roots, which generates physiological discrepancy because potassium ion is essential for the synthesis of

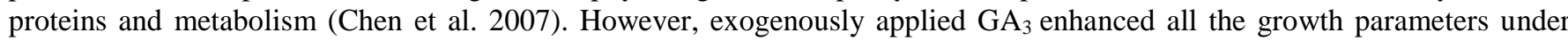
salinity stress as compared to their respective controls (Table 1). Similarly, Chauhan et al. (2019) reported that GA enhanced $_{3}$ the plant growth under the salinity condition. It might be due to the effect of $\mathrm{GA}_{3}$ which partially diminishes the toxic effect of salinity by increasing anti-oxidative, vigor, accumulation of osmolytes, and enzyme activities (Neelambari et al. 2018). Another study reported that decline in growth of plant under saline stress because of osmotic stress (Hakim et al. 2010).

Table 1- Effect of Gibberellic acid $\left(\mathrm{GA}_{3}, 100 \mathrm{mg} \mathrm{L}^{-1}\right)$ and salinity $\left(0,2,4 \mathrm{ds} \mathrm{m}^{-1}\right)$ on plant height, leaf blade length, root length, bulb diameter, root fresh weight, root dry weight and germination percentage of onion (phulkara variety) plants

\begin{tabular}{|c|c|c|c|c|c|c|c|}
\hline Treatments & $\begin{array}{l}\text { Plant height } \\
(\mathrm{cm})\end{array}$ & $\begin{array}{l}\text { Leaf blade } \\
\text { length }(\mathrm{cm})\end{array}$ & $\begin{array}{l}\text { Root length } \\
(\mathrm{cm})\end{array}$ & $\begin{array}{l}\text { Bulb } \\
\text { diameter } \\
(\mathrm{cm})\end{array}$ & $\begin{array}{l}\text { Root fresh } \\
\text { weight } \\
(\mathrm{g})\end{array}$ & $\begin{array}{l}\text { Root dry } \\
\text { weight } \\
(\mathrm{g})\end{array}$ & $\begin{array}{l}\text { Germination } \\
\text { percentage } \\
(G P \%)\end{array}$ \\
\hline Control & $46.7 \pm 1.10 \mathrm{ab}$ & $38.6 \pm 1.37 b$ & $12.5 \pm 0.77 \mathrm{ab}$ & $3.8 \pm 0.52 b$ & $56.6 \pm 2.71 b$ & $6.43 \pm 0.41 b$ & $77.7 \pm 3.2 b$ \\
\hline $\mathrm{GA}_{3}$ & $50.4 \pm 1.15 \mathrm{a}$ & $47.7 \pm 1.08 \mathrm{a}$ & $14.3 \pm 0.72 \mathrm{a}$ & $5.5 \pm 0.33 \mathrm{a}$ & $68.1 \pm 2.11 \mathrm{a}$ & $8.33 \pm 0.31 \mathrm{a}$ & $88.8 \pm 3.2 \mathrm{a}$ \\
\hline $2 \mathrm{dS} \mathrm{m}^{-1}$ & $43.7 \pm 0.92 b$ & $36.3 \pm 1.21 \mathrm{bc}$ & $11.6 \pm 0.50 \mathrm{~b}$ & $3.5 \pm 0.21 b$ & $41.5 \pm 2.06 \mathrm{~d}$ & $4.03 \pm 0.42 \mathrm{c}$ & $66.6 \pm 3.2 \mathrm{c}$ \\
\hline $2 \mathrm{dS} \mathrm{m}^{-1}+\mathrm{GA}_{3}$ & $45.1 \pm 1.82 \mathrm{~b}$ & $37.9 \pm 1.19 b c$ & $12.3 \pm 0.70 \mathrm{ab}$ & $3.7 \pm 0.29 \mathrm{~b}$ & $46.9 \pm 1.62 \mathrm{c}$ & $4.8 \pm 0.34 c$ & $83.3 \pm 3.2 \mathrm{ab}$ \\
\hline $4 \mathrm{dS} \mathrm{m}^{-1}$ & $34.7 \pm 1.99 \mathrm{c}$ & $33.6 \pm 1.35 \mathrm{c}$ & $7.4 \pm 0.81 \mathrm{c}$ & $2.5 \pm 0.28 \mathrm{c}$ & $33.6 \pm 2.19 \mathrm{e}$ & $2.9 \pm 0.55 \mathrm{~d}$ & $44.4 \pm 3.2 \mathrm{~d}$ \\
\hline $4 \mathrm{dS} \mathrm{m}^{-1}+\mathrm{GA}_{3}$ & $44.8 \pm 1.23 b$ & $36.7 \pm 1.55 \mathrm{bc}$ & $11.8 \pm 0.40 \mathrm{~b}$ & $3.3 \pm 0.08 b$ & $36.2 \pm 2.97 \mathrm{e}$ & $3.1 \pm 0.34 \mathrm{~d}$ & $75.9 \pm 4.8 b c$ \\
\hline
\end{tabular}

Each data values are represented as mean and $\underline{+} \mathrm{SD}$ of three replications and different lower case letters are representing the significant difference between treatments and same lower-case letters represent the no significant difference by according to LSD test $(\mathrm{P} \leq 0.05)$

Results of biochemical assays depict that salinity stress significantly have increased the activity of antioxidant enzymes (CAT, POD and SOD) as compared to control conditions (Figures 1-3). When the salinity was increased then the activity CAT, POD and SOD was increased maximum in onion. While foliar application of $\mathrm{GA}_{3}$ further enhanced the activity of CAT, POD and SOD under salinity stress as compared to their respective control. The basic function of POD in plants is to break down the hydrogen peroxide $\left(\mathrm{H}_{2} \mathrm{O}_{2}\right)$ which is very toxic and reactive element (Botella et al. 1994). Saline stress condition might be causing the univalent reduction in $\mathrm{O}_{2}^{-}$which produce hydrogen peroxide. In the salt stress condition, the level of $\mathrm{H}_{2} \mathrm{O}_{2}$ was reduced which was the damage of plant defence system due to the higher concentration of POD. Sancho et al. (1996) also stated same consequences in his study and recognized this to variations in the mechanical characteristics of cell wall which in turn, might be connected to the salinity adjustment mechanism. The enhancement of POD with $\mathrm{GA}_{3}$ under salinity stress (Figure 1) might be due to that $\mathrm{GA}_{3}$ increases the gibberellins which stimulates the decrease in hydrolytic enzymes and sugars (Mathew \& Murray 1968). $\mathrm{GA}_{3}$ have competition with saline conditions via improving the membrane permeability of plant cell and adjust the level of nutrients in cell. Eventually this leads to increase the growth, and $\mathrm{GA}_{3}$ also has induced physiochemical variations which are responsible for the influence of salt tolerance (Amal \& Mohamed 2014). 


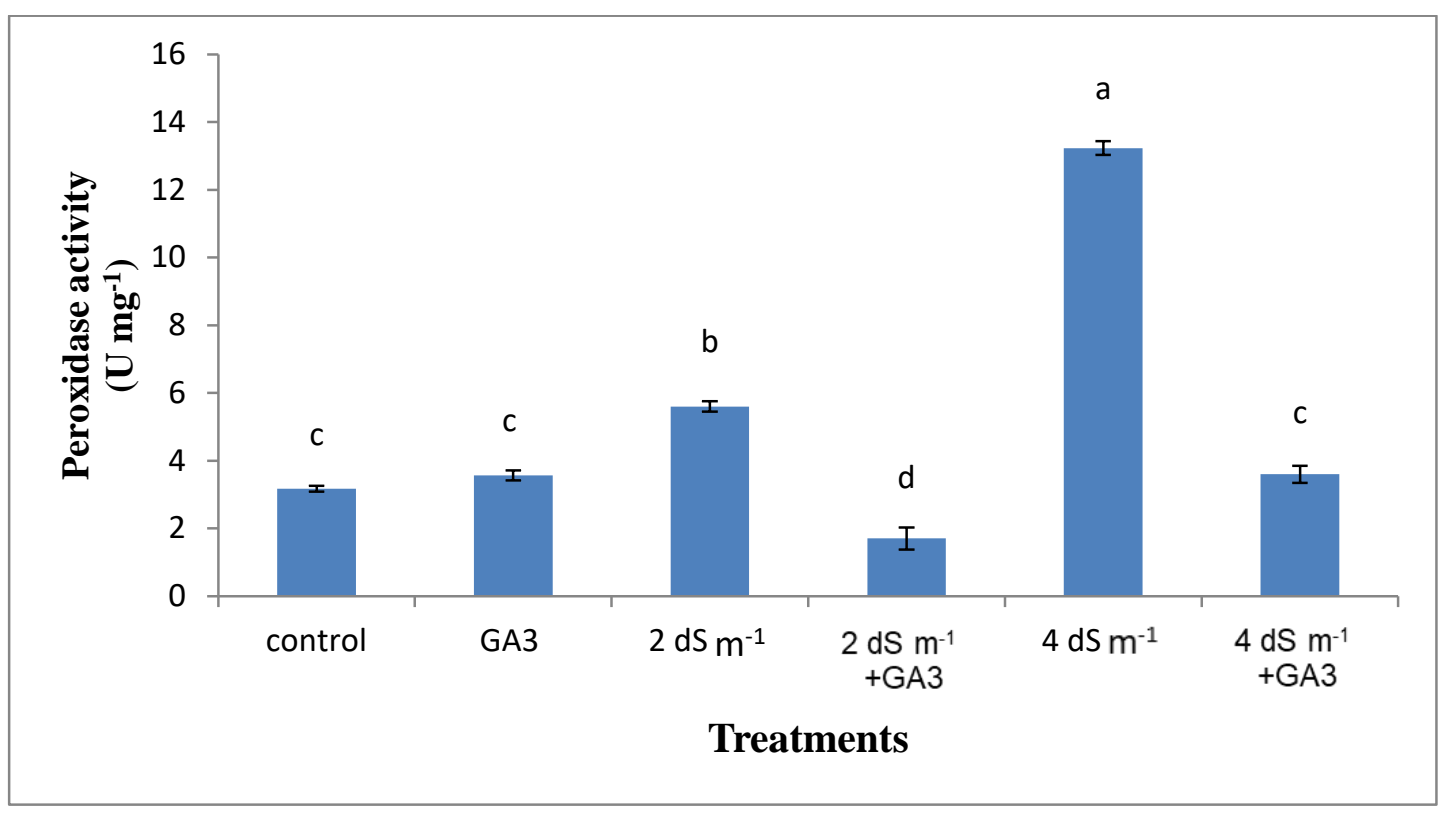

Figure 1- Effect of Gibberellic acid $\left(\mathrm{GA}_{3}, 100 \mathrm{mg} \mathrm{L}^{-1}\right)$ and salinity $\left(0,2,4 \mathrm{dS} \mathrm{m}^{-1}\right)$ on peroxidase activity (POD) of onion seedlings. Each data values are represented as mean and \pm SD of three replications and different lower-case letters are representing the significant difference between treatments and same lower-case letters represents the no significant difference by according to LSD test $(\mathbf{P} \leq \mathbf{0 . 0 5})$

Superoxide dismutase (SOD) is an important antioxidant which scavenges the reactive oxygen species (ROS) and it is activated under stress conditions. This is the reason that SOD enhanced in saline stress condition (Figure 2). It gives the initial line of protection against the noxious effects of stress. SOD eliminates superoxide radicals by catalyzing the dismutation of superoxides and reduces it to peroxide which is also oxidized by another antioxidant POD (Gill \& Tuteja 2010). Foliar spray of $\mathrm{GA}_{3}$ increased SOD activity to some extent because it increased the gibberellins which stimulate the decrease in hydrolytic enzymes and sugars (Mathew \& Murray 1968). The SOD decreased in saline treated plants by foliar treatment of GA 3 (100 $\mathrm{mg}$ $\mathrm{L}^{-1}$ ) as compared to control (Figure 2). It is due to that foliar application of GA 3 improves the membrane of plant cell and adjusts the level of nutrients in the cells (Chakrabarti \& Mukharji 2003). Eventually this leads to decrease in SOD, and GA 3 induces physiochemical variations which are responsible for the influence of salt tolerance (Amal \& Mohamed 2014).

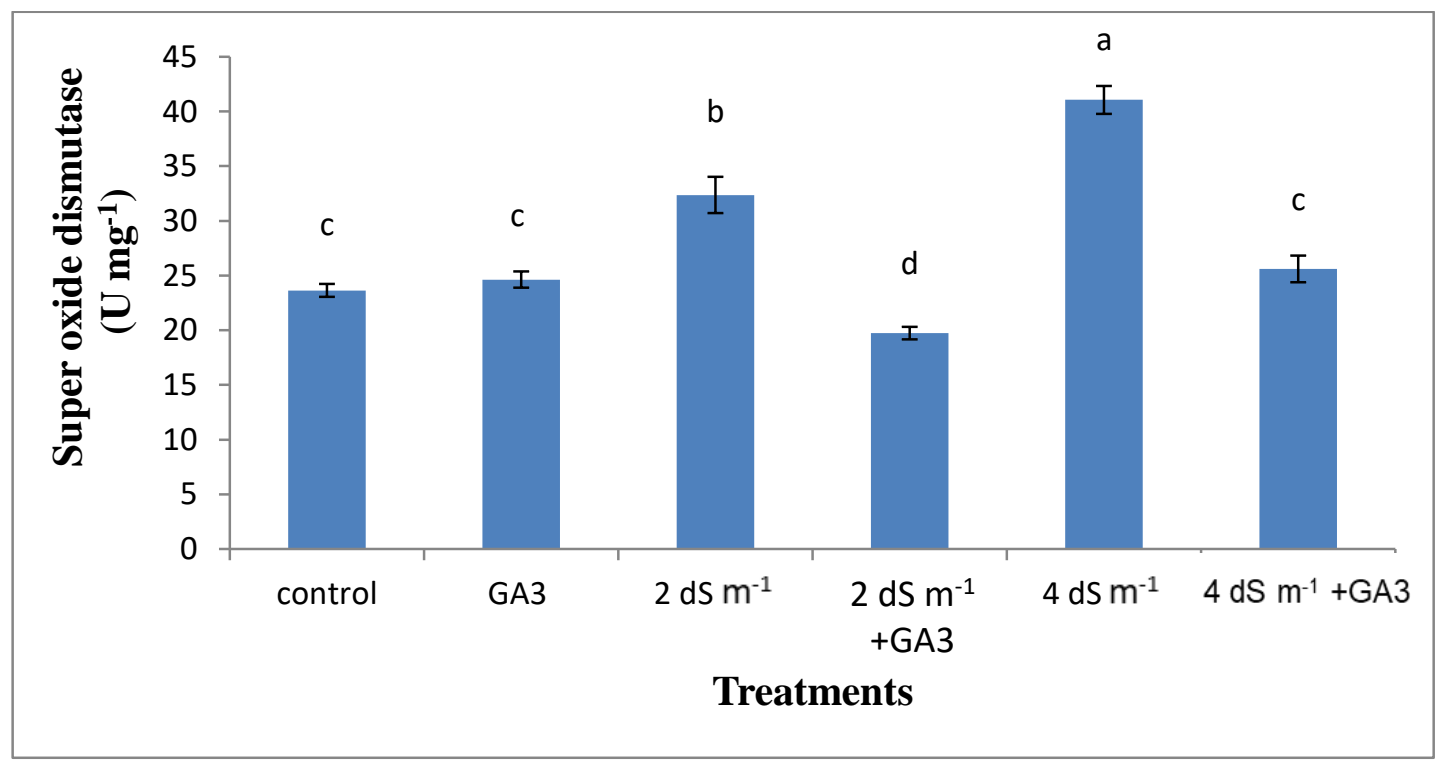

Figure 2- Effect of Gibberellic acid $\left(G_{3}, 100 \mathrm{mg} \mathrm{L}^{-1}\right)$ and salinity $\left(0,2,4 \mathrm{dS} \mathrm{m}^{-1}\right)$ on superoxide dismutase activity (SOD) of onion seedlings. Each data values are represented as mean and \pm SD of three replications and different lower-case letters are representing the significant difference between treatments and same lower-case letters represents the no significant difference by according to LSD test $(\mathbf{P} \leq \mathbf{0 . 0 5})$

Catalases (CAT) also plays important role in plant during the saline stress condition. During the saline stress condition, the CAT level increased as compared to control (Figure 3). Eyidogan \& Oz (2007) observed that CAT level was increased in the 
leaves of $C$. arietinum under saline conditions. In stress conditions, isoforms of CAT presents on different chromosomes which regulate independently (Scandalias 1990). CAT helps the plants to fight against oxidative stress that improves the plant growth (Polidoros \& Scandalios 1999). Exogenous application of $\mathrm{GA}_{3}$ improved the membrane permeability of plant cell and adjusts the level of nutrients in cell. This leads to decrease in CAT and also $\mathrm{GA}_{3}$ induce physiochemical variations which are responsible for the influence of salt tolerance (Chakrabarti \& Mukharji 2003; Amal \& Mohamed 2014).

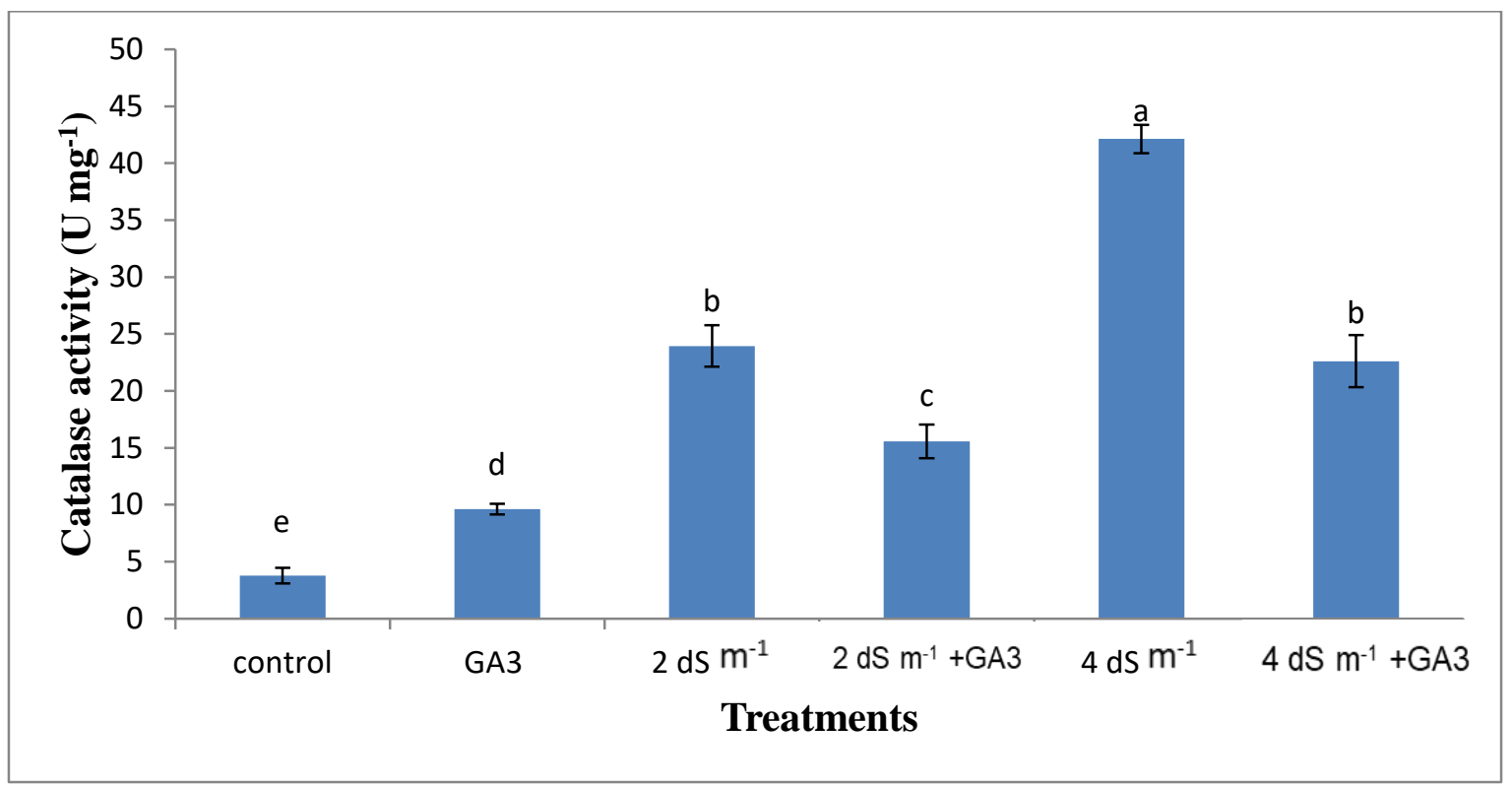

Figure 3- Effect of Gibberellic acid $\left(\mathrm{GA}_{3}, 100 \mathrm{mg} \mathrm{L}^{-1}\right)$ and salinity $\left(0,2,4 \mathrm{dS} \mathrm{m}^{-1}\right)$ on catalase activity (CAT) of onion seedlings. Each data values are represented as mean and \pm SD of three replications and different lower-case letters are representing the significant difference between treatments and same lower-case letters represents the no significant difference by according to LSD test $(\mathbf{P} \leq \mathbf{0 . 0 5})$

Total soluble proteins (TSP) has been observed lower when the plants are grown under saline toxic soils (Zhang et al. 2009), some proteins which have defensive mechanism, stimulated the plant growth under salinity and tolerate against salt stress (Aghaei et al. 2008). Significant effects of $\mathrm{GA}_{3}$ and $\mathrm{NaCl}$ and its interaction was observed on TSP contents in onion (Figure 4). TSP contents firstly increased at low salinity levels with $\mathrm{GA}_{3}$ and then the contents of TSP decreased at high concentrations of salinity level (Figure 4). The similar results were also found by Jiao et al. (2019) in caster bean as the concentration of GA 3 increased, the TSP content first increased and then decreased.

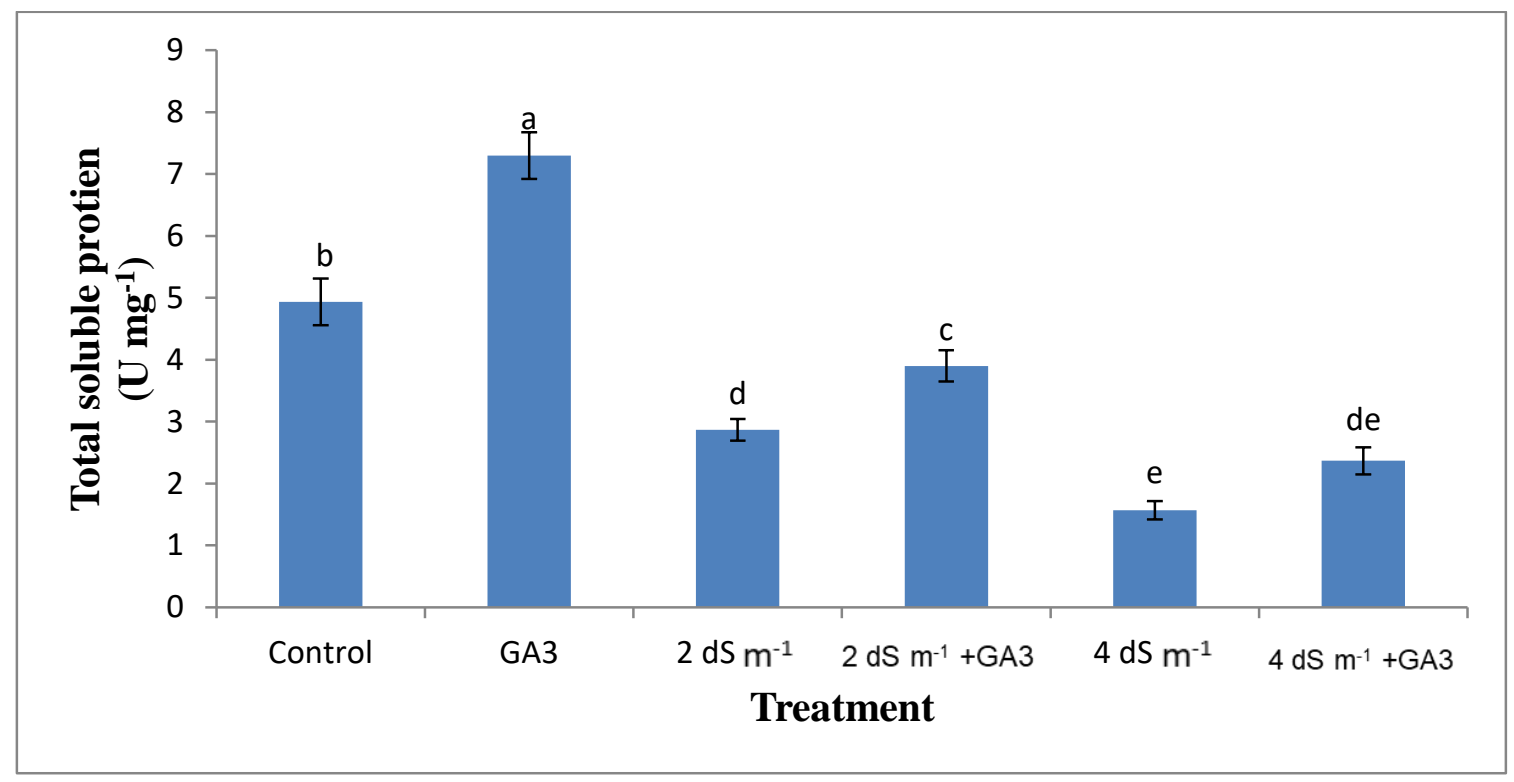

Figure 4- Effect of Gibberellic acid (GA3, $\left.100 \mathrm{mg} \mathrm{L}^{-1}\right)$ and salinity $\left(0,2,4 \mathrm{dS} \mathrm{m}^{-1}\right)$ on SOD, POD, CAT, soluble protein, and proline content of onion seedlings. Each data values are represented as mean and $\pm \mathrm{SD}$ of three replications and different lower-case letters are representing the significant difference between treatments and same lower-case letters represents the no significant difference by according to LSD test $(\mathbf{P} \leq \mathbf{0 . 0 5})$ 


\section{Conclusions}

Our findings revealed that the salinity stress significantly reduced plant growth parameters in onion seedlings. However, exogenously applied $\mathrm{GA}_{3}$ significantly enhanced the plant growth and by reducing oxidative stress. Interestingly, a decline was observed in antioxidant enzyme activities (SOD, POD and CAT) with the application of $\mathrm{GA}_{3}$ in saline stress conditions. Although these activities were increased to maximum level at salinity stress alone treatment. It is concluded from our study that we can enhance the growth of onion plant in saline stress with the foliar application of $\mathrm{GA}_{3}$. Less is known about the mechanism of $\mathrm{GA}_{3}$ in onion under salinity stress. Hence, to check the mechanism and role of $\mathrm{GA}_{3}$ under saline conditions in different plant species more study is required.

\section{References}

Adamicki F \& Kepka A K (1974). Storage of onions in controlled atmospheres. Acta Horti Culturae 38: 53-74 https://doi.org/10.17660/ActaHortic.1974.38.5

Aebi H E (1983). Catalase. In: Bergmeyer H U (Ed.), Methods of enzymatic analysis, Verlag Chemie, Weinhem, pp. 273-286

Aghaei K, Ehsanpour A A, Balali G \& Mostajeran A (2008). In vitro screening of potato (Solanum tuberosum L.) cultivars for salt tolerance using physiological parameters and RAPD analysis. American-Eurasian Journal of Agricultural and Environmental Sciences 3: 159-164

Allen R G, Pereira L S, Raes D \& Smith M (1998). Crop evapotranspiration-guidelines for computing crop water requirements-FAO Irrigation and drainage paper 56. Food and Agriculture Organization, Rome

Ali M A, Hossain M M, Zakaria M, Hossain T, Naznin A \& Islam M M (2015). Effect of GA 3 on quality seed production of onion in Bangladesh. Eco-Friendly Agriculture Journal 8(03): 47-50

Amal M E \& Mohamed A H H (2014). The effect of the exogenous gibberellic acid on two salt stressed barely cultivars. European Scientific Journal 10: 228-245

Botella M A, Quesada M A, Kononowicz A K, Bressan, R A, Pligo F, Hasegawa P M \& Valpuesta V (1994). Characterization and in situ localization of a salt-induced tomato peroxidase mRNA. Plant Molecular Biology 25: 105-114 https://doi.org/10.1007/BF00024202

Brewster J L (1994). Onions and other vegetable alliums. Wallingford, Oxfordshire, CAB International, $236 \mathrm{pp}$ UK

Chakrabarti N \& Mukharji S (2003). Alleviation of $\mathrm{NaCl}$ stress by pretreatment of phytohormones in Vigna radiata. Biologia Plantarum 46: 589-594 https://doi.org/10.1023/A:1024827931134

Chauhan A, Abu-Amarah B A, Kumar A, Verma J S, Ghramh H A, Khan K A \& Ansari M J (2019). Influence of gibberellic acid and different salt concentrations on germination percentage and physiological parameters of oat cultivars. Saudi Journal of Biological Sciences 26: 12981304 DOI: 10.1016/j.sjbs.2019.04.014

Chen Z C, Tracey A, Meixue Z, Amanda T, Bodapati N \& Sergey S (2007). Compatible solute accumulation and stress-mitigating effects in barley genotypes contrasting in their salt tolerance. Journal of Experimental Botany 58: 4245-4255 DOI: 10.1093/jxb/erm284

Demisie R \& Tolessa K (2017). Growth and bulb yield of onion (Allium cepa L.) in response to plant density and variety in jimma, south western Ethiopia. Advances in Crop Science and Technology 6: 357 DOI: 10.4172/2329-8863.1000357

Dhindsa R S, Plumb-Dhindsa P L \& Reid D M (1982). Leaf senescence and lipid peroxidation: effects of some phytohormones, and scavengers of free radicals and singlet oxygen. Physiologia Plantarum 56: 453-457 https://doi.org/10.1111/j.1399-3054.1982.tb04539.x

El-Shaieny A H (2015). Seed germination percentage and early seedling establishment of five (Vigna unguiculata L. (Walp) genotypes under salt stress. European Journal of Experimental Biology 5: 22-32

Eyidogan F \& OZ M T (2007). Effect of salinity on antioxidant responses of chickpea seedlings. Acta Physiologiae Plantarum 29: 485-493

FAO (2012). The State of Food and Agriculture. Retrieved in 2012 from http://www.fao.org/publications/sofa/2012/en/

Gill S S \& Tuteja N (2010). Reactive oxygen species and antioxidant machinery in abiotic stress tolerance in crop plants. Plant Physiology and Biochemistry 48: 909-930 DOI: 10.1016/j.plaphy.2010.08.016

Hakim M A, Juraimi A S, Begum M, Hanafi M M, Ismail M R \& Selamat A (2010). Effect of salt stress on germination and early seedling growth of rice (Oryza sativa L.). African Journal of Biotechnology 9: 911-1918 DOI: 10.5897/AJB09.1526

Jiao X, Zhi W, Liu G, Zhu G, Feng G, Nimir N E A, Ahmad I \& Zhou G (2019). Responses of foreign ga3 application on seedling growth of castor bean (Ricinus communis L.) under salinity stress conditions. Agronomy 9: $274 \mathrm{https}$ ://doi.org/10.3390/agronomy9060274

Khan M H \& Panda S K (2008). Alterations in root lipid peroxidation and antioxidative responses in two rice cultivars under NaCl-salinity stress. Acta Physiologiae Plantarum 30: 91-89 https://doi.org/10.1007/s11738-007-0093-7

Kumar A, Dutt S, Bagler G, Ahuja P S \& Kumar S (2012). Engineering a thermo-stable superoxide dismutase functional at subzero to $50^{\circ} \mathrm{C}$, which also tolerates autoclaving. Scientific Reports 2: 387 https://doi.org/10.1038/srep00387

Maggio A, Barbieri G, Raimondi G \& Pascale S (2010). Contrasting effects of GA3 treatments on tomato plants exposed to increasing salinity. Journal of Plant Growth Regulation 29:63-72 https://doi.org/10.1007/s00344-009-9114-7

Mathew A H \& Murray A M (1968). The effect of Gibberellic acid on peroxidase levels in barley. Planta 83: 387-389 https://doi.org/10.1007/BF00387618

Munns R \& Tester M (2008). Mechanisms of salinity tolerance. Annual Review of Plant Biology 59: 651-681 https://doi.org/10.1146/annurev.arplant.59.032607.092911

Nasri N, Maatallah S, Saidi L \& Lachaal M (2017). Influence of salinity on germination, seedling growth, ion content and acid phosphatase activities of Linum usitatissimum L. Journal of Animal and Plant Sciences 27(2): 517-521

Neelambari, Mandavia C \& Ganesh S S (2018). Curative Effect of Ascorbic Acid and Gibberellic Acid on Wheat (Triticum astivum L.) Metabolism under Salinity Stress. International Journal of Current Microbiology and Applied Sciences 7(1): 522-533

Olszewski N, Sun T P \& Gubler F (2002). Gibberellin signaling: biosynthesis, catabolism, and response pathways. Plant Cell 14: 61-80 DOI: $10.1105 /$ tpc. 010476

Onsa G H, Saari N, Selamat J \& Bakar J (2004). Purification and characterization of membrane-bound peroxidases from metroxylon sagu. Food Chemistry 85: 365-376 https://doi.org/10.1016/j.foodchem.2003.07.013

Polidoros A N \& Scandalios J G (1999). Role of hydrogen peroxide and different classes of antioxidants in the regulation of catalase and glutathione S-transferase gene expression in maize (Zea mays L.). Physiologia Plantarum 106:112-120 https://doi.org/10.1034/j.13993054.1999.106116.x 
Rayment G E \& Higginson F R (1992). Australian laboratory handbook of soil and water chemical methods, Melbourne, in kata press. pp. 330 Sancho M A, Forchettis M, Pliego F \& Valpuesta M A (1996). Peroxidase activity and isoenzymes in culture medium of NaC1 adapted tomato suspension cells. Plant Cell, Tissue and Organ Culture 44: 161-166 https://doi.org/10.1007/BF00048195

Scandalias J G (1990). Response of plant antioxidant defense genes to environmental stress. Advances in Genetics 28: 1-41 DOI: $10.1016 / \mathrm{s} 0065-2660(08) 60522-2$

Sedmak J J \& Grossberg S E (1977). A rapid, sensitive, and versatile assay for protein using Coomassie brilliant blue G250. Analytical Biochemistry 79: 544-552 https://doi.org/10.1016/0003-2697(77)90428-6

Stia-Baba, Hachicha M, Mansour M, Nahdi H \& Kheder M B (2010). Response of onion to salinity. The African Journal of Plant Science and Biotechnology 4(2): 7-12

Taiz L \& Zeiger E (2002). Plant Physiology, $3^{\text {rd }}$ ed. Publisher Sinauer, Sunderland, UK

Tester M \& Devenport R (2003). Na+ tolerance Na+ transport in higher plants. Annals of Botany 91: 503-527 https://doi.org/10.1093/aob/mcg058

Ubeda T S, Federici F \& Casimiro I (2009). Gibberellins signaling in the endodermis controls arabidopsis root meristem size. Current Biology 19: 1194-1199 https://doi.org/10.1016/j.cub.2009.06.023

Zhang X G, He Q Y, Li C J, Meng M L \& Wang X D (2009). Change in osmoregulation substances in potato under mixed salt stress. Chinese Potato Journal 23: 129-132

(C) 2021 by the authors. Licensee Ankara University, Faculty of Agriculture, Ankara, Turkey. This article is an open access article distributed under the terms and conditions of the Creative Commons Attribution (CC BY) license (http://creativecommons.org/licenses/by/4.0/). 